\title{
RESIDENTIAL CONSTRUCTION ACTIVITY IN OECD ECONOMIES
}

\section{Philip Arestis, University of Cambridge, UK, and University of the Basque Country, Spain}

\author{
Ana Rosa González, University of the Basque Country, Spain
}

\begin{abstract}
Four years after the burst of the housing bubble in some of the main world economies, the recovery does not follow a homogeneous pattern among them. For instance, some economies, like the US, have experienced a weak recovery, while the situation in other countries, like Spain, it is still far from even such. In this context, it is necessary to pay attention to the evolution of residential investment, which traditionally has played an important role in the revival of the economy after previous episodes of bubbles in the housing market. We propose a theoretical explanation of the determinants of real residential investment in order to identify those channels which can be used by policy makers to soften the evolution of cycles in this particular market. In the second stage of our study, we estimate our theoretical framework utilising a sample of 18 OECD countries for the period 1970 to 2011 . We utilise a specific linear function for each economy, which we estimate by applying the standard cointegration technique that permits us to obtain a long-run equilibrium relationship and analyse the dynamics in terms of a short-run relationship along with an error-correction term.
\end{abstract}

Keywords: Housing market, OECD countries, empirical modelling, cointegration, error correction.

JEL Classification: C22, R31. 


\section{Introduction}

The devastating consequences of the housing bubble, which took place in several OECD economies in 2007, are still present in most of them, thereby preventing economic revival. In this context, it is important to analyse the behaviour of investment in housing during the pre- and post-crisis period. The reason, which justifies this kind of analysis, is the fact that traditionally residential investment has recovered quickly after an economic collapse. In particular, the acquisition of dwellings and the activity in other sectors, which are related like furniture or electronic consumer goods, have been powerful elements in the recovery in previous episodes (The Economist, 2012b). However, in terms of the 'great recession' house prices are still falling in most affected countries and the level of residential construction activity is low four years after the collapse of the market (Feroli et al., 2012). Moreover, the dynamics of the residential construction sector need to be analysed since this sector can be considered a strategic one, due to its high impact on GDP, employment and the all important 'pulling' effects, which arise from its activity. In other words, real estate investment has been revealed as a key variable in the development of the economic cycle (Leamer, 2007). By taking into account all these empirical observations, and related theoretical premises, a study of the determinants of residential investment is essential.

For the purpose of this contribution a theoretical model of real residential investment is proposed. This relates residential investment to a number of variables such as real disposable income, real house prices, real interest rates for housing loans, unemployment rates and the volume of banking credit. The theoretical framework permits us to introduce further determinants of residential investment such as the evolution of demographics and the impact of monetary policy through two different channels: the mortgage rate and credit. The theoretical model is subsequently estimated in the case of 18 OECD economies over the period 1970-2011. The standard cointegration technique is utilized, which permits us to study the short-run disequilibrium and the long-run equilibrium relationships along with the errorcorrection term.

The remainder of this paper is organized as follows. In section 2 we develop our theoretical explanation of residential investment. Section 3 concentrates on the empirical aspects of the study. Sub-section 3.1. discusses the econometric technique employed; sub-section 3.2. focuses on the data utilised; and our econometric analysis is portrayed in section 3.3., where the empirical results are reported for the long- and the short-run relationships. Section 4 discusses the overall results and their 
implication in terms of the focus of this study. Finally, concluding remarks are provided in section 5 .

\section{Modelling Real Residential Investment}

This contribution concentrates on modelling, at the macro level, the most important investment decision undertaken by households, i.e. the purchase of a dwelling, in the case of 18 OECD countries. Our study tries to fill an existing gap in the housing literature, since as far as we can tell the majority of the empirical studies are either old (Alberts, 1962; Fair, 1972), or they are focused on just one country. ${ }^{1}$

To analyse the dynamics of the real estate market we need to identify those agents who participate in this market and encapsulate their behaviour by using two functions, i.e. demand of and supply for housing. Our model considers the interaction among five types of participants: households, house builders, public sector, monetary authorities and banking system. We may note that in the short run, the development of the market is constrained by the supply since it is given. As a result, increasing demand will press housing prices quickly in this time horizon. However, in the long run the supply becomes more elastic and the equilibrium of the market is achieved by means of quantity adjustments.

The consideration of dwelling as an asset permits one to summarise those forces which interact in the real estate market by means of the traditional supply and demand model. ${ }^{2}$ According to this general framework, the quantity demanded of a good or service mainly depends on consumers' income, its price and the price of related goods or services. On the other hand, the quantity offered by the suppliers of the market is a function of its price and the cost of the inputs, which are required for its production. This basic model can be enhanced by including other factors such as preferences, information, expectations, public regulation, and other. By applying this general notion to our study, we propose equations (1) and (2) which display the specification of the demand for and the supply of housing at the steady state and constitute the foundations of our model:

$D_{H}=D_{H}\left(P_{H}, R D Y, M R, C, U N\right)$

\footnotetext{
${ }^{1}$ We may refer to two examples of studies that concentrate on single countries to make the point. The study by Rodríguez and Bustillo (2010), which focuses on foreign real estate investment in Spain; and the study by by Leamer (2007), which provides empirical evidence of the real residential investment in the United States.

${ }^{2}$ See, for example, Perloff (2009) for a general presentation of this approach.
} 
where the demand for housing, $D_{H}$, is negatively related to housing prices, $P_{H}$, mortgage rate, $M R$, and the rate of unemployment, $U N$, but positively related to real disposable income per capita, $R D Y$, and to the volume of banking credit, $C$. The sign below a variable indicates the partial derivate of the dependent variable with respect to that variable.

$$
\begin{gathered}
S_{H}=S_{H}\left(P_{H}, R R I, U N\right) \\
+++
\end{gathered}
$$

where $S_{H}$ stands for the supply of housing. $P_{H}$ and $U N$ are as defined in equation (1) and affect the supply of housing positively; and RRI stands for real residential investment, which also affects $S_{H}$ positively.

At the long-run equilibrium where the demand for and the supply of housing are equal, solving the resulting equilibrium relationship with respect to real residential investment, equation (3) is derived:

$$
R R I=R R I\left(P_{H}, R D Y, M R, C, U N\right)
$$

where all the variables are as above.

Our contribution emphasises the proposition that increasing housing prices, $P_{H}$, accelerates real residential investment, i.e. further acquisition of new dwellings is undertaken since individuals expect that this rise in housing prices lasts in the future. As a result, households prefer investing today in this particular asset, which will be less affordable in the future according to their expectations. ${ }^{3}$ Following Shiller (2007), we consider housing as a speculative asset for the purposes of this contribution. ${ }^{4}$ In terms of our model, expectations affect the behaviour of agents in different ways. Specifically, some of the households, who are expecting house price appreciation, decide to enter the housing market and acquire new properties during the boom in order to obtain affordable assets, which according to their psychology will be more expensive in the near future. This effect, which comes from the demand side of the market, fuels the loop of residential investment-housing prices and transforms the

\footnotetext{
${ }^{3}$ Hirata et al. (2012) suggest that the procyclicality of housing prices could be the result of the connections between housing market and residential investment.

${ }^{4}$ Shiller's (2007) argument is based on behavioural economics and illustrates his view by means of three different crises: the U.S. Construction Boom of the 1950s, the U.S. Farmland Boom of the 1970s and the 2005 Turnaround London Housing Prices.
} 
initial expectations in the real trend of the market. ${ }^{5}$ At the same time, some homeowners sell their properties to materialise the expected capital gains and the subsequent increase in their wealth that rising housing prices makes possible. We may also note that during the booms of the market this asset is considered as a 'safe heaven' by households. This consideration makes residential investment more attractive, which favours the demand for housing, and finally, the volume of acquisition of dwelling.

Moreover, rising housing prices give an incentive to home builders to develop their activity since the possibilities of obtaining extraordinary profits are higher. The collapse of the housing market takes place when demand for housing slows down and it is not enough to absorb the increase in the supply of this asset, due to the fact that property developers are building new residences and some homeowners are selling their assets. ${ }^{6}$ As a result, the volume of dwelling transaction declines and housing prices fall in order to eliminate the excess of dwelling, which appears in the market. When the price is low enough and households are solvent enough to borrow resources from the banking sector, i.e. their degree of indebtedness is low and they satisfy the credit standards, a new cycle in the market takes place. This is so since agents can obtain the mortgages, which are required to finance transactions in this market. ${ }^{7}$ Hikes in housing prices also favour real estate activity through the 'collateral' channel. This is so since rising housing prices permit households to withdraw more resources backed by the value of the property, which makes possible a higher number of transactions in the market. ${ }^{8}$

Equation (3) suggests a positive relationship between real residential investment and real disposable income, $R D Y{ }^{9}$ This effect is easily understood by

\footnotetext{
${ }^{5}$ Shiller (2007) argues that households base their decisions on their expectations about the future. More specifically, if they expect an increase in the value of their main property, they start purchasing housing today due to expected higher price for this asset in the near future. At the same time households change their current property for a new one with better 'quality'. This is so since they perceive that a rise in their wealth and the funds that they can obtain through the mortgage equity withdrawal are higher. This is expected to boost the economy, which finally produces a rise in housing prices. This argument illustrates the notion of self-fulfilling prophecies coined by Merton (1968), which suggests that agents' forecasts can materialise due to the existence of a feedback between their predictions and their behaviour.

${ }^{6}$ The shortage of demand for housing emerges when there is no solvent home buyers who can obtain external finance under the current credit standards.

${ }^{7}$ This kind of bubbles in the housing market takes place more often than in the equity market (Bordo and Jeanne, 2002).

${ }^{8}$ See Corrado (2007) and Aoki et al. (2002) for further explanations of the 'collateral' channel.

${ }^{9}$ Ketchum (1954) pointed out at an early stage that real disposable income per capita was an important variable in the determination of housing demand. Other attempts to include disposable income in the residential investment relationship approximate this variable by including wages (for example, Poterba, 1984; Gounopoulus et al., 2012).
} 
considering any kind of measure of affordability, which in general terms is defined as the price-to-income ratio (The Economist, 2012). ${ }^{10}$ In this sense, an increase in income implies an improvement in the affordability of the dwelling, which makes possible a higher number of transactions in the housing market. There are also some additional effects of increasing disposable income. Such a situation permits an increase in the volume of the mortgage that the household can afford and reduces its risk premium, since the possibility of default of the borrower is reduced at the same time that the share of the income available for the repayment of the mortgage declines. These factors also contribute to making this asset more attractive, which means an increase in its demand, and a positive effect on dwelling acquisitions. According to the dynamics of our model, this increase in real residential investment boosts the supply of housing, and as a result, a slowdown in housing price appreciation takes place. ${ }^{11}$ We may also note that fiscal authorities play a role in the determination of real disposable income by two different channels: establishing the level of taxation over income and through the impact of public expenditure. In terms of our framework, a reduction in the level of taxation means an increase in the disposable income of households, which can be used to purchase a dwelling. This rise in the availability of income boosts the demand for dwelling since this asset becomes more affordable and an acceleration of the activity in the residential sector takes place.

In our framework, an increase in the cost of external finance implies that home buyers have to spend a rising fraction of their income to satisfy interest payments on debt. ${ }^{12}$ This factor forces some potential buyers to abandon the market since a decline in the affordability of the asset takes place in view of the increase in the cost of external finance. As a result, there is a contraction in the demand for housing, which means a slowdown in real residential investment. ${ }^{13}$ This decline in the demand for housing has also an effect on house prices whose appreciation decreases. The latter effect favours an increase in demand, although, the effect which prevails is the one captured in equation (1), i.e. the negative impact of the rate of interest on housing loans, $M R$, on real residential investment. Moreover, equation (3) shows how real

\footnotetext{
${ }^{10}$ See Feroli et al. (2012) for an example of the evolution of housing affordability in the United States since 1982.

${ }^{11}$ Benito et al. (2006) point to an improvement in households' income expectations as one of the key factors, which have been fuelled demand for housing in the past.

${ }^{12}$ Shiller (2007) also accounts for this relationship and provides empirical evidence on the evolution of residential investment and interest rates in the United States.

${ }^{13}$ The debt service burden, which is defined as the ratio of interest payments on consumer debt to nominal disposable income, can be considered as another measure of affordability (Arestis and Karakitsos, 2007).
} 
residential investment can be fuelled by the development of credit, $C{ }^{14}$ This relationship, which is stronger than the previous one, had been favoured during the boom prior to the 'great recession' by the relaxation of the credit standards and cheap credit, which permitted the access to housing by the households who were unable to do it in a period with a hard prudential policy. Given this relationship all those measures that stimulate the refinancing will have a positive effect and stimulate the recovery of the housing market (Feroli et al., 2012). ${ }^{15}$ We may note that the positive impact of credit on real residential investment, through the demand for housing, finally accelerates housing prices, whose effect have a positive incidence on residential activities through expectations, as has been argued above. The inclusion of these two variables reflects the main channels that monetary authorities have an impact upon the evolution of this market. On the one hand, by means of monetary policy, i.e. fixing the interest rate that influences the mortgage rate, which in its turn influences residential investment. ${ }^{16}$ On the other hand, monetary authorities can also play a role in this market by means of prudential policy in the form of credit standards. A relaxation of credit standards improves the affordability of the asset and permits the entrance in the market of more home buyers; this boosts demand for housing and accelerates real residential investment. This increase in the number of purchases of dwelling increases housing prices in the long run, which curbs the demand for housing.

Furthermore, our contribution suggests how rising unemployment reduces the acquisitions of new properties due to the lack of income by those households that are unemployed. This reduction in the share of households, which potentially can purchase dwellings, slows down the demand for housing, and as a result, a reduction in real residential investment takes place. This negative effect on real residential investment, which emanates from the presence of unemployment, $U N$, is accounted for in equation (3). The decline in real residential investment induced by rising unemployment and the subsequent fall of housing prices appreciation is bound to be more intense in those areas where the presence of 'sub-prime' loans is significant. This is so, since a huge fraction of borrowers that obtain this kind of credit are likely

\footnotetext{
${ }^{14}$ Arsenault et al. (2012) explore the development of real estate cycles by accounting for phenomena such as debt financing of real estate investment.

${ }^{15}$ Peek and Wilcox (2006) also point to the importance of credit in the evolution of real residential investment. Specifically, Peek and Wilcox (op. cit.) produce empirical evidence in the case of the United States, which supports the argument that the existence of well-developed financial markets contribute to reducing the volatility of real residential investment.

${ }^{16}$ See Maisel (1968) for further explanations of the impact of monetary policy on residential structures. Particularly, Maisel (op.cit.) suggests that a rise in the interest rate provokes an increase in the cost of mortgages, which reduces the demand for housing and the profitability of construction activities; the latter affects housing supply negatively.
} 
to lose their low quality employment during the recession (see Abel and Deitz, 2010, for relevant empirical evidence based on New York data). The relationship between real residential investment and unemployment is in both directions, since housingrelated economic activity has an important role in the creation of employment. ${ }^{17}$ For instance, in the United States at the peak of the housing bubble, residential activities were responsible for $5.1 \%$ of total employment (Byun, 2010). In this sense, a high level of activity in the market provokes the creation of employment and increases the income of a share of households that decide to acquire new assets, which produces the circuit. In this context, we may also note that the evolution of real residential investment is crucial in the determination of the short-run cycles, and in the level of employment and income in this time horizon. ${ }^{18}$ Despite the existence of this bidirectionality, the direction of the causation that prevails is the one which goes from unemployment to real estate investment, since after the burst of the market there is no recovery until the time when the employment in the economy as a whole increases. Specifically, it is necessary for a decline in unemployment, which permits the recovery of the income and thereby an increase in demand for housing. ${ }^{19}$

Table 1 summarises the dynamics in the short run among the mentioned factors, which finally provide the long-run equilibrium relationship in steady state, as shown in equation (3). Our contribution does not consider the housing market as an efficient one. It updates the traditional theoretical frame, as for example in Poterba (1984), by accounting for the presence of the financial sector, i.e. by including the volume of credit and the real mortgage rate. The loop residential investment-housing prices captures the relationship among housing prices, demand for housing, real residential investment and supply of housing and it is at the centre of our theoretical framework. In terms of our model, an external shock, which modifies the affordability of the asset and affects the demand for housing, creates disequilibrium between demand for and supply of housing in the short run. This kind of shocks include, for example, a change in land use planning, a reduction in taxation over income, an expansion of public expenditure, a relaxation in credit standards or a reduction in the cost of external finance, amongst others. Moreover, shocks in unemployment can also modify the demand for housing and generates the disequilibrium as just mentioned. These disequilibria can induce home builders to alter the supply of housing, since in

\footnotetext{
${ }^{17}$ Feroli et al. (2011) and Hilbers (2008) also emphasize the importance of real residential activities on unemployment.

${ }^{18}$ However, the possibility of growth in the long run is not influenced by this kind of investment, but is determined by business investment, which also has an important role in the creation of the potential employment and the explanation of the long-run business cycles. See Leamer (2007) for a discussion of the role of housing in the business cycle.

${ }^{19}$ Feroli et al. (2011) also point to the fact that the presence of high unemployment influences significantly the housing market.
} 
the short run the effect of these external shocks is absorbed by prices due to the fact that supply of housing is fixed in this time horizon. ${ }^{20}$ This increase in prices also has an effect on the demand for housing, since hikes in house prices are understood by homeowners and house builders as a signal of the possibility of obtaining capital gains, which contributes to the expansion of this market. ${ }^{21}$ This increase in the activity of the construction sector exerts strong 'pulling' effects on the economy, as it is reflected by the creation of an important number of jobs, directly as well as indirectly. This decline in unemployment contributes to increasing the demand for housing and favours another loop in the market. In this context, where there are strong preferences for housing, an increase in the value of the 'collateral' that households own to obtain new mortgages takes place, which induces a relaxation in credit standards and an improvement in the affordability of external finance. ${ }^{22}$ Both factors also facilitate households' investments in real estate. The system collapses when demand is not strong enough to absorb increases in the supply of real estate. ${ }^{23}$ At that point, property developers stop the execution of new projects and prices start to fall in order to achieve a new equilibrium in the long run.

TABLE 1 THE RESIDENTIAL INVESTMENT CyCLE

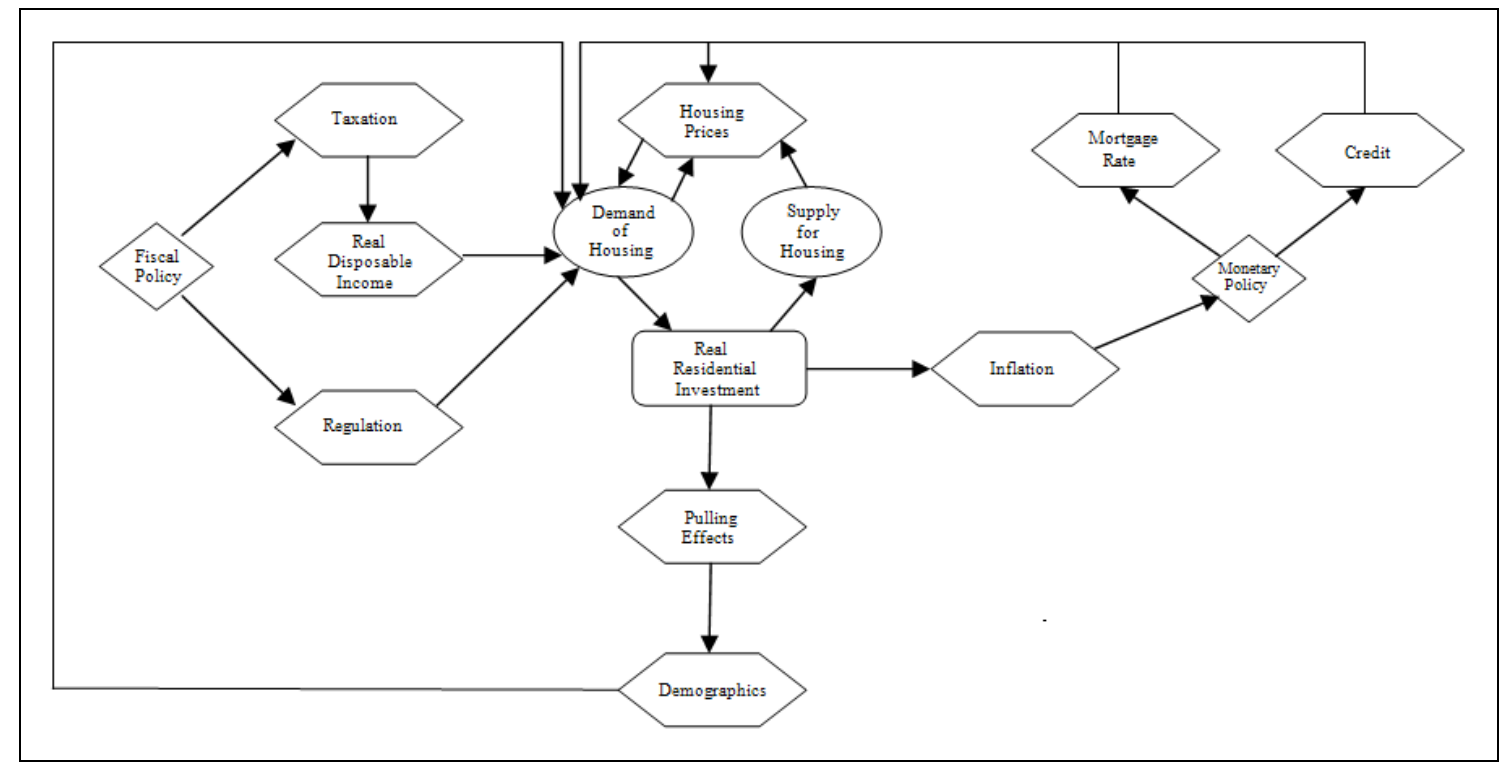

${ }^{20} \mathrm{An}$ increase in demand for housing means a rise in the acquisition of dwelling, i.e. an increase in residential investment. In the long run, the rise in residential investment promotes an expansion of supply of housing, since some homeowners are willing to sell their properties to materialise those capital gains, which are related to the hikes in housing prices.

${ }^{21}$ In this context, we may consider the case where households' expectations anticipate that dwellings will be less affordable in the future, which provokes that they prefer investing today in this particular asset and contributes to fuel the circuit.

${ }^{22} \mathrm{We}$ may note that long lasting increases in real estate activities increase the demand for consumer goods and construction inputs. This promotes inflation, and this effect has to be accounted for by monetary policy.

${ }^{23}$ A slowdown in demand can happen due to the existence of liquidity constraints, a toughening of credit standards, an increase in the mortgage rates or the presence of negative expectations. 


\section{Empirical Analysis}

We begin our empirical analysis with a discussion of the econometric technique employed in our estimations.

\subsection{The Econometric Technique}

We study the presence of unit roots in our sample by means of the augmented DickeyFuller (Dickey and Fuller; 1979, 1981) tests, the Phillips-Perron (Phillips and Perron, 1988) test and the GLS-based Dickey-Fuller (Nelson and Plosser, 1982) test. These three tests examine whether a unit root in the relevant variable exists. We also apply the Kwiatkowski-Phillips-Schmidt-Shin (Kwiatkowski et al., 1992) test, which checks for stationarity. These unit root/stationarity tests are used to avoid the possibility of producing the wrong order of integration. This could emerge in view of the existence of structural breaks, which would produce wrong conclusions and incorrect unit roots for the variables involved. To the extent that these tests show the presence of unit roots this would permit us to apply the standard cointegration technique to avoid spurious regressions in the case of lack of stationarity in the variables utilized.

We employ the standard cointegration technique (see Hendry and Nielsen, 2007, for further details and references; also Engle and Granger, 1987 for the purposes of our empirical analysis). This requires two steps. First, we start with the estimation of the long-run cointegrating relationship by applying Ordinary Least Squares (OLS). The residuals of the long-run relationship are then analyzed to check for stationarity by means of the standard unit root/stationarity tests. This technique requires that all the variables are cointegrated. Specifically, we apply the augmented Dickey-Fuller (Dickey and Fuller; 1979, 1981) test and the Kwiatkowski-PhillipsSchmidt-Shin (Kwiatkowski et al., 1992) test. Second, the short-run dynamics are estimated along with an error-correction variable. The latter captures the disequilibria from the long-run equilibrium, by including it as an explanatory variable in the form of the residuals of the long-run regression lagged by one period. In order to estimate the short-run models we apply the 'general to specific' modelling strategy (Hendry and Richard, 1983), which suggests starting the estimation procedure by a general model, which includes several lags of the endogenous and the exogenous variables. Gradually those lags, which are not significant, are dropped from the main regression until the stage is reached where the model computes just the significant lags.

In order to validate our long-run econometric results we report the R-squared, the DW statistics, the Akaike Information Criterion (AIC), the Schwartz Information 
Criterion (SIC) and the F-statistics. $^{24}$ Furthermore, some additional diagnostic/statistics are applied to the short-run relationships: a) the Breusch-Godfrey Serial Correlation LM (Breusch, 1979; Godfrey, 1978) one, which tests for the absence or otherwise of autocorrelation of first-, second- and third-order; b) the White (White, 1980) test, with and without cross terms, which permits us to corroborate the homoscedasticity of the residuals; c) the ARCH (Engle, 1988) test, which checks for the lack of ARCH effects of first- and second-order; and d) the Jarque-Bera (Jarque and Bera; 1980, 1981) test to study the skewness and kurtosis of the residuals.

Finally, we may note that in order to model the real residential investment function we linearise the relationship proposed in equation (3). As a result, we proceed to estimate the model as displayed in equation (4):

$R R I=\psi_{0}+\psi_{1} R D Y-\psi_{2} M R+\psi_{3} P_{H}+\psi_{4} C-\psi_{5} U N$

where the symbols have the same meaning as in equation (3).

We turn our attention next to a discussion of the data employed for estimation purposes.

\subsection{Data}

In order to estimate our testable hypothesis we collect data for 18 OECD countries covering the period 1970-2011. More specifically, the 18 countries selected for this purpose are: Australia, Belgium, Canada, Denmark, Finland, France, Germany, Italy, Ireland, Japan, Netherlands, New Zealand, Norway, Spain, Sweden, Switzerland, the United Kingdom and the United States. The size of the sample is big enough to analyse the development of real residential investment in countries where the impact of the housing bubble has been different. The length of this sample, which contains the main European countries and other important world economies, is in accordance with the period as in the Bank of International Settlements (BIS), where annual data of Real House Prices Index are published since 1970. ${ }^{25}$

We have obtained the rest of the data that we employ to estimate our testable hypothesis from the $A M E C O$ databank, which is developed by the European

\footnotetext{
${ }^{24}$ The AIC and SIC allow the choice of the most suitable models when there are several specifications for the same relationship. They suggest selecting the estimation that shows the lowest value for these statistics, since by implication this regression is the one that has the highest R-squared statistic. Furthermore, the specification that contains the lowest values for AIC and SIC is the one that fits better to the structure of the analysed data (Gujarati, 1997).

${ }^{25}$ This information is available on the following website:
} http://www.bis.org/ 
Commission's Directorate General for Economic and Financial Affairs. ${ }^{26}$ This source offers annual macroeconomic information on the following variables that we employ for our purpose: a) Unemployment Rate; b) Gross Fixed Capital Formation by type of Goods at Current Prices (Dwelling); c) Real Long-term Interest Rate; ${ }^{27}$ d) Gross National Disposable Income per Head of Population; and e) Gross Domestic Product Price Deflactor.

We may note that this databank presents some missing information. Specifically, the dwelling time series in the case of Switzerland and Norway are not available but they are provided by the $O E C D$ databank (Gross fixed capital formation and housing). Moreover, the latter databank also publishes the long-term interest rate data, as required for our analysis and for the following economies: Australia, Canada, Norway, New Zealand and Switzerland. Apart from that, the World Bank database is also utilised, since it provides annual data on domestic credit to the private sector (as a percentage of GDP) for the period 1970 to 2011. This variable is used to approximate the volume of banking credit in the empirical part of our research. ${ }^{28}$

We employ the E-Views 5.0 statistical package to estimate the relationships and conduct the diagnostics/statistics.

\subsection{Econometric Analysis}

We begin the discussion in this section by referring to the testing procedure before we embark on the estimation of the long-run and short-run relationships. As explained in section 3.1, we apply several unit root/stationarity tests. More specifically, we find that the data are I(1) by accepting the null hypothesis of the augmented Dickey-Fuller (Dickey and Fuller; 1979, 1981) tests, the Phillips-Perron (Phillips and Perron, 1988) test and the GLS-based Dickey-Fuller (Nelson and Plosser, 1982) test. We also apply the Kwiatkowski-Phillips-Schmidt-Shin (Kwiatkowski et al., 1992) test whose null hypothesis is rejected. This result confirms the order of integration as shown in the case of the unit root tests, and just mentioned above. ${ }^{29}$

\footnotetext{
${ }^{26}$ This databank can be obtained from: http://ec.europa.eu/economy finance/db indicators/ameco/index en.htm

${ }^{27}$ The presence of missing information in the European Mortgage Federation (2011) relating to the rate of interest on mortgages compels us to approximate this variable by the long-term interest rate (AMECO, 2011).

${ }^{28}$ The data mentioned in the text can be obtained from: http://data.worldbank.org/

${ }^{29}$ The results of all the unit root/stationarity tests referred to in the text are not reported in the paper but
} can be obtained from the authors upon request. 


\subsubsection{Long-run Equilibrium Relationships}

The long-run equilibrium relationships, which we estimate for the purpose of this contribution, are displayed in Table 3A. In order to validate our results we apply several tests that are shown in Table 3B.

TABLE 3A REAL RESIDENTIAL INVESTMENT LONG-RUN RELATIONSHIPS (1970-2011)

\begin{tabular}{|c|c|c|c|c|c|c|}
\hline & Constant & L_RDI & MR & L_RHP & L_C & L_UN \\
\hline Australia & -1.921 & $1.622 *(0)$ & & & $0.542 *(0)$ & \\
\hline Belgium & $-1.856^{*}$ & $0.816^{*}(0)$ & & $0.413 *(0)$ & & \\
\hline Canada & $-3.449^{*}$ & $0.912 *(0)$ & & $0.902 *(0)$ & $0.151 * * *(0)$ & \\
\hline Denmark & $-5.771^{*}$ & $1.227^{*}(0)$ & & $0.566^{*}(0)$ & & $-0.175^{*}(0)$ \\
\hline Finland & $-2.268^{*}$ & $0.786^{*}(0)$ & $-1.031^{*}(0)$ & $0.390 *(0)$ & & \\
\hline France & 0.375 & $0.717^{*}(0)$ & $-1.404 *(0)$ & $0.296 *(0)$ & & $-0.162 *(0)$ \\
\hline Germany & $1.962 * * *$ & & $-3.645^{* *}(0)$ & $0.630 * *(0)$ & $1.609 *(0)$ & \\
\hline Ireland & $-3.368^{*}$ & $1.588^{*}(0)$ & & & & $-0.215^{* *}(0)$ \\
\hline Italy & $0.927^{* *}$ & $0.741^{*}(0)$ & & & $0.190 *(0)$ & $-0.401^{*}(0)$ \\
\hline Japan & $7.586^{*}$ & & & $0.414 *(0)$ & $0.692^{*}(0)$ & \\
\hline Netherlands & $-2.246^{*}$ & $1.342 *(0)$ & & $0.179 * *(0)$ & & $-0.079^{*}(0)$ \\
\hline New Zealand & $-4.648^{*}$ & $1.247 * *(0)$ & & $0.409 * * *(0)$ & $0.421 *(0)$ & $-0.113^{*}(0)$ \\
\hline Norway & $-1.106 * *$ & $0.701 *(0)$ & & & & $-0.340^{*}(0)$ \\
\hline Spain & $-1.295 *$ & $1.879 *(0)$ & $-1.018^{* *}(0)$ & & & $-0.112 *(0)$ \\
\hline Sweden & -0.032 & & & $0.740 *(0)$ & $0.746^{*}(0)$ & $-0.228^{*}(0)$ \\
\hline Switzerland & $-4.982 *$ & $1.936^{*}(0)$ & & & & \\
\hline UK & $-0.379 * *$ & $0.549 *(0)$ & & $0.431^{*}(0)$ & & $-0.089 *(0)$ \\
\hline US & $-3.911^{*}$ & $2.353 *(0)$ & & & & $-0.546^{*}(0)$ \\
\hline
\end{tabular}

Note: $*, * *$ and $* * *$ indicate statistical significance and rejection of the null at the 1,5 and 10 percent significance levels, respectively. Numbers in parentheses, in the case of the variables, show the lag(s) of the relevant variable.

TABLE 3B REAL RESIDENTIAL INVESTMENT LONG-RUN RELATIONSHIPS: DIAGNOSTICS/STATISTICS I

\begin{tabular}{|c|c|c|c|c|c|c|}
\hline & R-squared & DW & AIC & SIC & F-statistics & Jarque-Bera \\
\hline Australia & 0.95455 & 0.807738 & -1.246751 & -1.118785 & $378.0361(0.0000)$ & $1.229148(0.540871)$ \\
\hline Belgium & 0.850192 & 0.44083 & -0.885435 & -0.761316 & $110.6663(0.0000)$ & $3.266632(0.195281)$ \\
\hline Canada & 0.961772 & 0.639201 & -1.95315 & -1.782528 & $293.5211(0.0000)$ & $0.478504(0.787217)$ \\
\hline Denmark & 0.970636 & 1.547125 & -2.591647 & -2.42447 & $407.6828(0.0000)$ & $1.082923(0.582188)$ \\
\hline Finland & 0.941595 & 0.795121 & -2.190022 & -2.022844 & $198.8352(0.0000)$ & $2.554503(0.278803)$ \\
\hline France & 0.970827 & 0.992602 & -3.96573 & -3.756758 & $299.5069(0.0000)$ & $1.405211(0.495293)$ \\
\hline Germany & 0.893493 & 0.572136 & -1.470615 & -1.303437 & $103.4654(0.0000)$ & $0.894595(0.639354)$ \\
\hline Ireland & 0.958098 & 0.600785 & -0.771361 & -0.639401 & $377.2724(0.0000)$ & $4.113704(0.127856)$ \\
\hline Italy & 0.939399 & 0.627122 & -3.012061 & -2.844884 & $191.1844(0.0000)$ & $0.630715(0.729528)$ \\
\hline Japan & 0.775316 & 0.530566 & -1.557195 & -1.431812 & $65.56333(0.0000)$ & $0.949853(0.621931)$ \\
\hline Netherlands & 0.972166 & 1.132838 & -2.786235 & -2.619058 & $430.7772(0.0000)$ & $1.935129(0.380007)$ \\
\hline New Zealand & 0.928155 & 0.938326 & -0.902008 & -0.686537 & $106.5802(0.0000)$ & $2.116487(0.347065)$ \\
\hline Norway & 0.731021 & 0.520813 & -1.168111 & -1.040145 & $48.91966(0.0000)$ & $1.261304(0.532245)$ \\
\hline Spain & 0.970866 & 0.380259 & -1.920852 & -1.753674 & $411.0001(0.0000)$ & $2.633616(0.267989)$ \\
\hline Sweden & 0.652276 & 0.906508 & -0.253997 & -0.086819 & $23.1354(0.0000)$ & $0.956777(0.619781)$ \\
\hline Switzerland & 0.848352 & 0.424086 & -1.756688 & -1.673099 & $218.1737(0.0000)$ & $2.463226(0.291822)$ \\
\hline UK & 0.953702 & 0.781927 & -2.115491 & -1.949999 & $260.9212(0.0000)$ & $0.556856(0.756973)$ \\
\hline US & 0.903823 & 0.612855 & -0.919123 & -0.795004 & $183.2516(0.0000)$ & $1.670077(0.433858)$ \\
\hline
\end{tabular}


The estimated models confirm our testable hypothesis, which assumes that real disposable income is the key element of the affordability of housing, and as the central determinant of real residential investment. The highest impact of income is in the case of the United States (2.353), Switzerland (1.936) and Spain (1.879). The incidence of this variable is still remarkable in other countries where the coefficients are over unity, as in Australia (1.622), Ireland (1.588), the Netherlands (1.342), New Zealand (1.247) and Denmark (1.227). Its positive influence is reasonable in the case of Canada (0.912), Belgium (0.816), Finland (0.786), Italy (0.741), France (0.717) and Norway (0.701). The lowest influence appears in the case of the United Kingdom (0.549).

In terms of the mortgage rate, its negative impact is only significant in four of the economies under consideration. The highest depressing impact is found in Germany (-3.645). However, the impact is almost half of the German case in France (-1.404) and slightly lower in Finland (-1.031) and Spain (-1.018).

Moreover, our results highlight the importance of the 'collateral' channel and the 'amplification effect' derived from increasing housing prices. The most relevant effect is found in Canada (0.902) and Sweden (0.740), although the estimated coefficients are still significant in Germany (0.630) and Denmark (0.566). The lowest values for this parameter appear in France (0.296) and the Netherlands (0.179). In the rest of the countries, where this variable plays a role, the value of the estimator is around 0.4. More specifically, this is evident in the cases of the United Kingdom (0.431), Japan (0.414), Belgium (0.413), New Zealand (0.409) and Finland (0.390).

Furthermore, our study shows how an increasing volume of credit in the economy can favour the acquisition of dwellings. The impact of this variable is the strongest in Germany (1.609). Its incidence is also positive but much more modest in Sweden (0.746), Japan (0.692), Australia (0.542) and New Zealand (0.421). However, the lowest estimated values are found in Canada (0.151) and Italy (0.190).

Next we comment on the unemployment variable. The strongest depressing effect emerges in the United States (-0.546), Italy (-0.401) and Norway (-0.340). The impact of this variable is still considerable in Sweden (-0.228) and Ireland (-0.215). The latter coefficients are slightly lower by comparison to those of Denmark (-0.175) and France (-0.162). However, the magnitude of the estimated unemployment coefficient is not very strong in New Zealand (-0.113) and Spain (-0.112). The lowest values of this parameter are in the case of the Netherlands (-0.079) and the United Kingdom (-0.089) residential sector.

As mentioned above, Table $3 \mathrm{~B}$ shows all the statistics that we employ to validate our econometric regressions. In the majority of cases examined, the R- 
squared is higher than $90 \% .{ }^{30}$ It is, however, slightly lower in Germany (89\%), Belgium and Switzerland (85\%), and even lower in Norway and Sweden (70\%). The DW statistic is provided in the second column. All the DW values, except in the case of Denmark, are below 1.5 and far from 2 since the data are I(1) and there is autocorrelation. However, we can accept these models due to the fact that the technique we employ compels us to check for possible presence of autocorrelation just in the short-run model (Hendry and Nielsen, 2007); this is undertaken in section 3.3.2, where it is clearly shown that autocorrelation does not exist in this case. The AIC and the SIC, which are reported in the third and fourth columns, show negative values, since the adjustment of the model is high. We may say that the models which are displayed in Table 3A, were chosen among several alternatives by selecting the one with the lowest absolute value (Gujarati, 1997). The fifth column displays the Fstatistic, whose null hypothesis is rejected as the p-value is equal to 0 . As a result, the joint significance of the estimators is acceptable. The last column presents the JarqueBera statistic. In all cases the null hypothesis of normality is accepted since the pvalues are higher than 0.05 .

The previous analysis highlights some similarities among the countries, which are included in our sample. Real residential investment in the United States is determined by real disposable income and the evolution of unemployment. These determinants are also important in the cases of United Kingdom, Denmark and the Netherlands, where the real housing price plays a role too. The same explanatory elements are found in the New Zealand case, where in addition the volume of credit is also significant. A similar common structure of variables appears in Sweden, although in this case disposable income is not significant. This model is similar to those estimated for the Japanese and the German markets. However, in the Japanese market the volume of credit is not significant, and also in the case of the European countries, where in addition the unemployment rate is not significant; in the latter case, though, the mortgage rate is more important.

Moreover, real residential investment is explained by real disposable income, mortgage rate and real housing price in Finland and France. The banking credit is also a significant determinant in the French market. There are also other similarities among Ireland, Norway and Spain, where the determinants of the residential construction activity are real disposable income and unemployment along with the mortgage rate, which is significant too. However, real disposable income is the only significant variable in the case of Switzerland. This model is enlarged by including

\footnotetext{
${ }^{30}$ This statistic captures the impact of changes in the independent variables, as contained in the estimated relationship, on the dependent variable, which is in this case real residential investment.
} 
the impact of real housing prices in Belgium, the effect of credit in Australia and both elements in the case of the Canadian market.

Finally it should be noted that the estimated models include an intercept, which is significant in all the cases except for the Australian, French and Swedish housing markets.

\subsubsection{Short-Run Dynamics}

The results of the models estimated for the purposes of the short-run dynamics in the residential sector are shown in Table $4 \mathrm{~A} .^{31}$ Tables $4 \mathrm{~B}$ and $4 \mathrm{C}$ display those diagnostics/statistics, which test for the validity of the estimated models.

TABLE 4A REAL RESIDENTIAL INVESTMENT SHORT-RUN RELATIONSHIPS (1970-2011)

\begin{tabular}{|c|c|c|c|c|c|c|c|c|}
\hline & Constant & $\Delta \mathrm{L} \_\mathrm{RDI}$ & $\Delta \mathrm{MR}$ & $\Delta \mathrm{L} \_\mathrm{RHP}$ & $\Delta \mathrm{L} \_\mathrm{C}$ & $\Delta \mathrm{L}_{-} \mathrm{UN}$ & $\Delta \mathrm{L} \_\mathrm{RRI}$ & EL_RRI \\
\hline Australia & 0.020 & $1.941 *(0)$ & & & & & & $-0.390^{*}$ \\
\hline Belgium & $-0.040^{* * *}$ & $2.278 *(0)$ & $-2.014 * *(1)$ & $0.933 *(1)$ & & & & $-0.288 * *$ \\
\hline \multirow[t]{2}{*}{ Canada } & 0.007 & $1.491 *(0)$ & & $1.020 *(0)$ & & & & $-0.310 * *$ \\
\hline & & $-1.069^{*}(1)$ & & & & & & \\
\hline Denmark & -0.014 & $1.915 *(0)$ & $-1.132 * *(1)$ & $0.459 *(0)$ & & $-0.094^{* *}(0)$ & $0.221 *(1)$ & $-0.931 *$ \\
\hline Finland & -0.009 & $1.308 *(0)$ & & $0.329 *(1)$ & & & & $-0.464 *$ \\
\hline France & -0.002 & $1.041 *(0)$ & & & & $-0.162 *(0)$ & $0.341 *(1)$ & $-0.624 *$ \\
\hline Germany & $0.018 * * *$ & & & $0.603^{* * * *}(0)$ & & $-0.091^{* *}(0)$ & $0.472 *(1)$ & $-0.164 * * *$ \\
\hline \multirow[t]{2}{*}{ Ireland } & -0.006 & & & & & $-0.388^{* *}(0)$ & $0.378^{* *}(1)$ & $-0.261 * * *$ \\
\hline & & & & & & & $0.419 * *(2)$ & \\
\hline Italy & 0.003 & & & & $0.245^{* *}(1)$ & & $0.302 * *(1)$ & $-0.430^{*}$ \\
\hline Japan & $-0.019 * * *$ & $1.948 *(0)$ & & & & & & $-0.244^{*}$ \\
\hline Netherlands & -0.007 & $0.850 * *(0)$ & & $0.248^{* * *}(0)$ & & & $0.358^{* *}(1)$ & $-0.619^{*}$ \\
\hline New Zealand & -0.018 & $1.868 *(0)$ & & $1.171 *(0)$ & & & & $-0.390^{*}$ \\
\hline \multirow[t]{2}{*}{ Norway } & -0.001 & & & $0.669 *(0)$ & & & $0.541 *(1)$ & $-0.229 *$ \\
\hline & & & & $0.159^{* *}(2)$ & & & & \\
\hline Spain & 0.012 & $0.843^{* * *}(0)$ & & & & $-0.196^{* *}(0)$ & $0.325 *(1)$ & $-0.235^{* *}$ \\
\hline Sweden & -0.026 & $1.475^{* *}(0)$ & & $0.547^{* * * *}(1)$ & & & $0.500 *(1)$ & $-0.244 * *$ \\
\hline \multirow[t]{2}{*}{ Switzerland } & 0.012 & $0.765 *(0)$ & $-1.370^{* * *}(1)$ & & & & $0.421 *(1)$ & $-0.284^{*}$ \\
\hline & & $-1.193^{*}(2)$ & & & & & & \\
\hline \multirow[t]{2}{*}{ UK } & -0.012 & $2.375^{*}(0)$ & $-0.560^{* * * *}(0)$ & & & & $0.307 * *(1)$ & $-0.465^{*}$ \\
\hline & & $-1.011^{* *}(2)$ & & & & & & \\
\hline US & $-0.040 * *$ & $4.140 *(0)$ & & $1.037^{* *}(0)$ & & & & $-0.310 *(1)$ \\
\hline
\end{tabular}

TABLE 4B REAL RESIDENTIAL INVESTMENT SHORT-RUN RELATIONSHIPS: DiAGNOSTICS/STATISTICS I

\begin{tabular}{lrrrrrr}
\hline \multicolumn{2}{l}{ Diagnostic/Statistics Short-run Relationships } & & & & & \\
\hline & R-squared & DW & AIC & SIC & F-statistics & Jarque-Bera \\
\hline \multirow{2}{*}{ Australia } & 0.332024 & 1.735726 & -1.77725 & -1.647967 & $8.698561(0.0000)$ & $5.314656(0.070135)$ \\
Belgium & 0.570939 & 1.739181 & -2.065292 & -1.854182 & $11.64335(0.0000)$ & $0.394902(0.820820)$
\end{tabular}

${ }^{31}$ As stated above (sub-section 3.1), the 'general to specific' modelling strategy (Hendry and Richard, 1983 ) is applied in order to estimate the short-run models, and also decide on the lag structure of the variables involved. 


\begin{tabular}{|c|c|c|c|c|c|c|}
\hline Canada & 0.687928 & 1.449731 & -2.742073 & -2.526601 & $18.18621(0.0000)$ & $0.620575(0.733236)$ \\
\hline Denmark & 0.852349 & 1.831175 & -2.901116 & -2.602528 & $30.78787(0.0000)$ & $0.282388(0.868321)$ \\
\hline Finland & 0.713171 & 1.566718 & -2.782996 & -2.612375 & $29.008(0.0000)$ & $1.072050(0.585069)$ \\
\hline France & 0.821264 & 1.691152 & -4.914966 & -4.703856 & $40.20475(0.0000)$ & $1.092057(0.579246)$ \\
\hline Germany & 0.505603 & 1.61279 & -2.995545 & -2.782268 & $8.692649(0.0000)$ & $1.138743(0.565881)$ \\
\hline Ireland & 0.703977 & 1.779597 & -1.392341 & -1.167877 & $17.24133(0.0000)$ & $1.226492(0.541590)$ \\
\hline Italy & 0.361613 & 1.827852 & -3.525806 & -3.356918 & $6.797369(0.0000)$ & $3.093000(0.212992)$ \\
\hline Japan & 0.59022 & 1.688235 & -2.875654 & -2.750271 & $27.36638(0.0000)$ & $0.714030(0.699736)$ \\
\hline Netherlands & 0.551917 & 1.811423 & -3.007219 & -2.793942 & $10.46971(0.0000)$ & $2.911454(0.233231)$ \\
\hline New Zealand & 0.634159 & 1.428288 & -1.941182 & -1.767029 & $19.06775(0.0000)$ & $1.704872(0.426375)$ \\
\hline Norway & 0.646044 & 1.535014 & -2.670347 & -2.457069 & $15.51432(0.0000)$ & $1.990772(0.369581)$ \\
\hline Spain & 0.788316 & 1.939755 & -3.39446 & -3.181183 & $31.65419(0.0000)$ & $3.573216(0.167527)$ \\
\hline Sweden & 0.607498 & 1.832915 & -1.601336 & -1.388059 & $13.15596(0.0000)$ & $0.265270(0.875785)$ \\
\hline Switzerland & 0.623202 & 1.806911 & -3.264487 & -3.00592 & $10.58521(0.0000)$ & $0.785022(0.675359)$ \\
\hline UK & 0.763341 & 1.955608 & -3.025 & -2.766434 & $20.64313(0.0000)$ & $3.169609(0.204988)$ \\
\hline US & 0.677401 & 1.598857 & -1.920493 & -1.753316 & $25.89787(0.0000)$ & $5.377822(0.067955)$ \\
\hline
\end{tabular}

Note: In the last two columns numbers in parentheses indicates the p-value of each test.

TABLE 4C REAL RESIDENTIAL INVESTMENT SHORT-RUN RELATIONSHIPS: DIAGNOSTICS/STATISTICS II

\begin{tabular}{|c|c|c|c|c|c|c|c|}
\hline & LM (1) & LM (2) & LM (3) & White & White $\mathrm{X}$ & $\mathrm{ARCH}(1)$ & $\mathrm{ARCH}(2)$ \\
\hline Australia & $1.402722(0.244482)$ & $1.787987(0.183125)$ & $1.387100(0.264521)$ & $0.375810(0.824207)$ & $0.546686(0.739549)$ & $0.013069(0.909638)$ & $0.546686(0.739549)$ \\
\hline Belgium & $0.760909(0.389163)$ & $0.410098(0.666921)$ & $0.446087(0.721741)$ & $1.377966(0.244673)$ & $1.936227(0.072509)$ & $0.952074(0.335529)$ & $1.344257(0.273863)$ \\
\hline Canada & $2.956782(0.095178)$ & $1.443274(0.251584)$ & $0.948296(0.429743)$ & $1.966117(0.087527)$ & $1.203781(0.336024)$ & $0.207455(0.651582)$ & $0.525915(0.595885)$ \\
\hline Denmark & $0.315393(0.578428)$ & $0.165853(0.847942)$ & $0.350808(0.788842)$ & $0.912236(0.548303)$ & $0.784304(0.709759)$ & $0.056021(0.814241)$ & $0.064215(0.937917)$ \\
\hline Finland & $2.782208(0.104502)$ & $1.433123(0.253024)$ & $0.946585(0.429726)$ & $1.478741(0.216876)$ & $1.012084(0.453251)$ & $0.407105(0.527480)$ & $0.303454(0.740242)$ \\
\hline France & $1.13831(0.293527)$ & $0.56859(0.571774)$ & $0.368511(0.776210)$ & $1.555257(0.179033)$ & $0.921679(0.549777)$ & $0.777632(0.383559)$ & $1.742489(0.189930)$ \\
\hline Germany & $1.718171(0.198978)$ & $1.796254(0.182248)$ & $1.386725(0.265246)$ & $1.100684(0.390155)$ & $1.048646(0.444027)$ & $2.812209(0.102213)$ & $1.350681(0.272612)$ \\
\hline Ireland & $1.255773(0.271973)$ & $0.669915(0.520054)$ & $1.295772(0.296877)$ & $0.412072(0.902785)$ & $0.572033(0.854804)$ & $0.489297(0.489457)$ & $0.677237(0.515872)$ \\
\hline Italy & $0.995422(0.325269)$ & $0.483785(0.620625)$ & $0.727045(0.543160)$ & $0.859251(0.534658)$ & $0.851157(0.576820)$ & $0.071511(0.790634)$ & $1.096947(0.345094)$ \\
\hline Japan & $1.247738(0.271186)$ & $0.635385(0.535568)$ & $0.855055(0.473440)$ & $1.026511(0.406836)$ & $0.951293(0.460602)$ & $0.57946(0.451223)$ & $0.974569(0.387089)$ \\
\hline Netherlands & $0.170943(0.681949)$ & $1.441247(0.251582)$ & $1.572818(0.215781)$ & $1.046704(0.424740)$ & $1.501297(0.184789)$ & $0.090265(0.765568)$ & $2.429342(0.103239)$ \\
\hline New Zealand & $2.403575(0.130893)$ & $2.544988(0.094758)$ & $2.351552(0.092132)$ & $0.681053(0.666079)$ & $0.816825(0.605680)$ & $0.681053(0.666079)$ & $0.072625(0.930102)$ \\
\hline Norway & $1.518942(0.226489)$ & $1.910538(0.164506)$ & $1.961069(0.140364)$ & $0.905497(0.524861)$ & $0.902739(0.567189)$ & $0.118872(0.732268)$ & $1.89234(0.166255)$ \\
\hline Spain & $0.055196(0.815708)$ & $0.877651(0.425528)$ & $0.632075(0.599900)$ & $1.740524(0.129599)$ & $1.900043(0.080698)$ & $0.234024(0.631485)$ & $0.109711(0.896409)$ \\
\hline Sweden & $0.007467(0.931663)$ & $0.003761(0.996246)$ & $0.004574(0.999564)$ & $1.411876(0.231974)$ & $1.300087(0.276942)$ & $0.103122(0.749972)$ & $0.188458(0.829095)$ \\
\hline Switzerland & $0.137404(0.713397)$ & $1.410777(0.259676)$ & $1.543437(0.224377)$ & $1.501659(0.192692)$ & $2.61749(0.024926)$ & $2.787728(0.103910)$ & $1.273337(0.293290)$ \\
\hline UK & $0.01382(0.907175)$ & $1.396713(0.263037)$ & $1.163227(0.340656)$ & $0.288781(0.978108)$ & $0.645165(0.826715)$ & $0.712565(0.404327)$ & $0.528894(0.594168)$ \\
\hline US & $2.405023(0.129694)$ & $1.199038(0.313566)$ & $0.814017(0.495051)$ & $0.503947(0.800933)$ & $0.670612(0.728721)$ & $0.31803(0.576107)$ & $0.537021(0.589096)$ \\
\hline
\end{tabular}
Note: Numbers in parentheses indicates the p-value of each test.

The first column in Table 4A reports the estimated results on the intercept of the model, which is only significant in the case of Belgium (-0.040), Germany (0.018), Japan (-0.019) and the United States (-0.040). As in the long-run case, our analysis points to the real disposable income as the variable whose positive impact is more important and general. The highest impact appears in the United States (4.140), which is twice the one found in the cases of the United Kingdom (2.375), Belgium (2.278), Japan (1.948), Australia (1.941), Denmark (1.915) and New Zealand (1.868). This effect is slightly smaller in Canada (1.491), Sweden (1.475) and Finland (1.308), while the lowest incidence emerges in France (1.041), the Netherlands (0.850), Spain (0.843) and Switzerland (0.765). 
Regarding the financial elements that are taken on board, the cost of external finance, which could make less affordable the acquisition of a new property when it rises, is only relevant in Belgium (-2.014), Switzerland (-1.369), Denmark (-1.132) and the United Kingdom (-0.560). However, the volume of credit is only significant in the case of Italy (0.245).

The highest positive effect, which arises from real housing prices, appears in New Zealand (1.171), the United States (1.037), Canada (1.020) and Belgium (0.933), while the lowest impact is evident in Finland (0.329) and the Netherlands (0.248). Our model also highlights this variable as significant in Norway (0.669 and 0.159), Germany (0.603), Sweden (0.547) and Denmark (0.459).

The demographic factor that is estimated depresses real estate activities in the case of Ireland (-0.388), Spain (-0.196), France (-0.162), Denmark (-0.094) and Germany (-0.091).

Apart from these elements, the study of the short-run dynamics considers the value in the recent past of the variables under consideration as another determinant of the model. Real residential investment in the previous years has a strong impact on its current magnitude in Norway (0.541), Sweden (0.500) and Germany (0.472). This effect is still remarkable in Switzerland (0.421) and Ireland (0.378 and 0.419). Similar values for the first lag of residential investment are found in the Netherlands (0.358) and France (0.341), while the lowest coefficients for this variable appear in the case of Spain (0.325), the United Kingdom (0.307), Italy (0.302) and Denmark (0.221).

Moreover, the last column of Table 4A displays the value of the error-correction term. ${ }^{32}$ This term is extremely high in the case of Denmark, which is above $90 \%$, but less so in the Danish and the Netherlands markets (62\%). Around a $50 \%$ of the disequilibria are annually eliminated in Finland and the United Kingdom, while this percentage falls to $40 \%$ in the models estimated for Australia, Italy and New Zealand. The rest of the countries under consideration include markets, which are less dynamic than the previous ones. More specifically, we can put them into two groups: on the one hand, Belgium, Canada, Ireland, Switzerland and the United States where an errorcorrection term of around $30 \%$ is evident; on the other hand, those markets in which the adjustment takes place at a slower pace (i.e. 20\%) are Germany, Japan, Norway, Spain and Sweden.

Finally, these econometric results are validated by means of the diagnostic statistics as reported in Tables 4B and 4C. The first column of Table 4B reports the Rsquared. The highest values for this statistic are achieved in the case of the Danish

\footnotetext{
${ }^{32}$ The error-correction term shows how the short-run model tends to adjust to the long-run equilibrium. Specifically, this element shows the percentage of the adjustment towards the long-run equilibrium in each period.
} 
(85\%) and the French (82\%) models. The lowest value of the R-squared is found in the case of Italy (36\%) and Australia (33\%). The second column shows the value of the Durbin Watson statistic, which is close to 2 in the majority of cases. Only the Canadian and New Zealand estimations show a value below 1.5, but in all the cases the values are acceptable. The next two columns display the AIC and the SIC, which are negative. As stated above, Table 4A collects those models, which were selected among different specifications by choosing the one with the lowest absolute value. Specifically, the lowest the absolute value of the Information Criteria, the highest the adjustment of the model to the data. This is also indicated by other statistics like the R-squared. The last columns present the F-statistics, which state the joint significance of the determinants included in the estimated relationships, and the Jarque-Bera test, which examines, and supports, the normality of the residuals in all the cases.

Turning to the last group of tests, as shown in Table $4 \mathrm{C}$, the first three statistics clearly show the absence of autocorrelation of first-, second- and third-order. The two versions of the White test, which are reported in the next two columns, suggest homocedasticity in the residuals. Finally, the lack of ARCH effects of firstand second-order is provided by those tests, which are shown in the penultimate and ultimate columns of Table 4C. All the estimated parameters have the expected sign and support our testable hypothesis.

\section{Overall Discussion of the Econometric Results}

The econometric analysis, which is undertaken in section 3, supports our theoretical premise. In particular, our results point to real disposable income as the most relevant determinant of investment in dwelling. Our study also makes evident an important positive effect of housing prices on residential investment, since increasing housing prices boost household expectations about future returns of investing in this asset, which increase the demand for housing. ${ }^{33}$ Moreover, increasing housing prices provoke an increase in the 'collateral', which permits households to obtain more and cheaper credit to finance the new acquisitions of dwelling. Our empirical results also highlight a positive influence of the volume of credit on residential investment. This finding is consistent with our theoretical framework due to the fact that households need to finance the majority of the cost of acquiring this asset. However, our analysis finds two variables, which exert a depressing effect on real residential investment, as suggested in section 2. Particularly, the mortgage rate, which when higher provokes a fall in the affordability of the housing; and the rate of unemployment, whose negative impact is

\footnotetext{
${ }^{33}$ Our results show how the effect of housing prices on real residential investment that prevails is the one that emerges from the supply side of the market independently of the time horizon considered.
} 
more general than the one, which the previous variable exerts. This is so since rising unemployment depresses household and banking expectations and modifies the behaviour of those households who loose their income.

More specifically, our study considers real disposable income as the core of the residential investment decision, since this variable is one of the main determinants of the affordability of the asset under investigation. The results point to a positive and strong incidence of this variable on the level of activity in this sector in all the markets except in Germany. These findings provide empirical support to our theoretical framework, which suggests that the key determinant of the acquisition of dwellings is income. In the current situation, incomes are stagnant (Milanovic, 2011), due to the impact of elements like rising unemployment, which is affecting more strongly the youngest population groups and austerity measures in order to cope with excessive public deficit. Consequently, and in terms of the global context, the poor performance of the real residential investment, in comparison with previous experiences, is perfectly understandable and interpretable. Our findings also confirm a positive correlation between housing price appreciation and acquisition of dwellings. These findings are consistent with our theoretical hypotheses, which are also consistent with Shiller's (2007) amplification effect and the presence of the 'collateral' channel. The equilibrium relationships highlight the importance of the affordability of this asset in order to determine the volume of real estate investment. Focusing our attention on the ratio price to income, our results reveal income as the main determinant, as suggested above. The influence of the price of this asset can also alter households' potential wealth, and eventually, modifies their income if they sell the mentioned asset. That increase in households' wealth induces changes in the pattern of consumption and investment in durable goods, which have effects on other macro magnitudes, as for example, the current account balance in the short run, or the structure of the productive system in the long run.

Moreover, these empirical results confirm the importance of introducing the development of the banking sector in order to model residential investment. Firstly, the econometric results conclude that the relaxation of credit standards, which allows the volume of credit to expand, favours residential investment, since housing becomes easier and more affordable to acquire, as suggested by our theoretical framework. This impact is particularly strong in Germany and in other countries, which have suffered from bubbles in the housing market like Japan. Secondly, the mortgage rate, which determines the cost of banking finance, exerts the expected depressing effect on the activity of this particular sector. Both elements point to an important channel to act in the development of the housing market, which was ignored by the traditional model of 
Poterba (1984). According to our findings, the role of the mortgage rate remains in the background in comparison with the necessity of a strong prudential policy, which exerts an incidence on the demand for credit, and on the volume of transactions of dwelling, which are taking place in the market. The weak impact of the mortgage rate on residential investment could be justified by recalling that the impact of this variable in the market is also captured partially through the volume of credit in the system.

The negative effect of unemployment on household behaviour, which provokes a decline of demand for housing due to the lack of income, should be emphasised in view of its significance. Also, the incidence of unemployment on the banking sector expectations, i.e. the tightening of the credit standards when unemployment increases, which are suggested in the theoretical part of this contribution, are also confirmed by the econometric estimations.

The presence of significant lags in the real residential investment in the disequilibrium relationships confirms that in the short run adjustments in the housing market take place through changes in prices, while the adjustment in the stock of dwelling requires several years. This softens the effect of a burst in terms of unemployment, since after the collapse of the market some property developers try to complete their projects and reduce the price of their assets in favour of their sales. Depending on the intensity of the bubble, after this initial stage, decreases in employment can take place faster.

\section{Concluding Remarks}

This paper puts forward a theoretical model, which identifies the main determinants of real residential investment. This is a key variable in terms of the supply side of the housing market and a relevant indicator of the level of economic activity in this market. More specifically, this contribution shows how real residential investment is positively related with real disposable income, housing prices and the volume of banking credit. We also suggest a negative effect on real residential investment that emerges from the rate of interest on loans for housing and the volume of unemployment of the economy under consideration.

The theoretical model is subsequently estimated by means of a sample that comprises of 18 OECD economies from 1970 to 2011. All the relationships are estimated by using the standard cointegration technique. After checking for the presence of unit roots in our data, we apply a procedure in two stages. This permits us to estimate the long-run equilibrium relationship, and obtain the short-run model by using the residuals of the long-run relationship in the form of the error-correction variable and applying the 'general to specific' modelling strategy. 
The analysis also accounts for the role that policy makers and monetary authorities in particular have for avoiding bubbles during expansionary periods and contribute to the revival of the housing market after the collapse. Our analysis points to the disposable income as the key variable in order to invest in real estate. According to this finding, the recovery of the housing market needs income growth, and relevant economic policies to achieve it, as for example, regulation about the use of land or fiscal benefits after the acquisition of dwellings. In this sense, fiscal policy must be focused on the creation of stable employment for those who are potential buyers of their first dwelling, i.e. population between 25 and 44 years, since a recovery of the economy and the subsequent expansion of income will drive the recovery of the sector. Moreover, monetary authorities have two different channels to expand or slow down the activity in the housing market, i.e. monetary policy and prudential policy. Specifically, the control of the mortgage rate is helpful but it is not the most powerful element that the authorities can utilise to influence real residential investment; this is so since the volume of credit is more relevant than the mortgage rate. This proposition points to prudential policy as the most useful tool in order to contain the demand for housing of those households who are solvent enough to repay their debts. As a result we can highlight an asymmetric behaviour between fiscal and monetary policies. Namely, in the former case the authorities have to act in favour of the recovery, while in the latter they should play a containing role during the booms in the housing market.

\section{References}

Abel, J.R. and Deitz, R. (2010), "Bypassing the Bust: The Stability of Upstate New York's Housing Markets during the Recession”, Federal Reserve Bank of New York Current Issues in Economics and Finance, 16 (3): 1-9.

AMECO (2011), AMECO Databank List of Variables. Available at: http://ec.europa.eu/economy_finance/db_indicators/ameco/index_en.htm

Alberts, W.W. (1962); "Cycles, Residential Construction Cycles, and the Mortgage Market”, Journal of Political Economy, 70 (3): 263-281.

Aoki, K., Proudman, J. and Vlieghe, G. (2002), "Houses as a Collateral: Has the Link between House Prices and Consumption in the U.K. Changed?", FRBNY Economic Policy Review, 8 (1): 163-167.

Arestis, P. and Karakitsos, E. (2007), "Modelling the U.S. Housing Market", Ekonomia, 10 (2): 67-88. 
Arestis, P. and Karakitsos, E. (2011), Treating the US Housing as a Speculative Asset, Mimeo, Cambridge Centre for Economic and Public Policy, Department of Land Economy, University of Cambridge.

Arsenault, M., Clayton, J., and Peng, L. (2012), "Mortgage Funds Flows, Capital Appreciation, and Real Estate Cycles", Journal of Real Estate Finance and Economics, Forthcoming.

Benito, A., Thompson, J., Waldron M. and Wood, R. (2006), "House Prices and Consumer Spending”, Bank of England Quarterly Bulletin Summer, 142-154.

Blinder, A. and Esaki, H. (1978), "Macroeconomic Activity and Income Distribution in the Postwar United States", Review of Economics and Statistics, 60 (4): 604-609.

Bordo, M.D. and Jeanne, O. (2002), "Boom-Busts in Asset Prices, Economic Instability, and Monetary Policy", NBER Working Paper no. 8966, Cambridge MA: National Bureau of Economic Research.

Breusch, T.S. (1979), "Testing for Autocorrelation in Dynamic Linear Models", Australian Economic Papers, 17 (31): 334-355.

Byun, K.J. (2010), "The U.S. Housing Bubble and Bust: Impacts on Employment", Monthly Labor Review, December, 3-17.

Carroll, C.D., Misuzu, O. and Slacalek, J. (2011), "How Large Are Housing and Financial Wealth Effects? A new Approach", Journal of Money, Credit and Banking, 43 (1): 55-79.

Corrado, G. (2007), “Modelling Housing and Consumers' Spending under Liquidity and Borrowing Constraints: Some Stylised Facts from UK Housing Market", Ekonomia, 10 (2): 112-137.

Dickey, D. A. and Fuller, W.A. (1979), "Distribution of the Estimator for Autoregressive Time Series with a Unit Root", Journal of the American Statistical Association, 74 (366): 427-431.

Dickey, D.A. and Fuller, W.A. (1981), "Likelihood Ratio Statistics for Autoregresssive Time Series with a Unit Root”, Econometrica, 49 (4): 1057-1072.

Engle, R.F., and Granger, C.W.J. (1987), "Co-integration and Error Correction: Representation, Estimation and Testing", Econometrica, 55 (2): 251-276.

Engle, R. (1988), "Autoregressive Conditional Heteroscedasticity with Estimates of the Variance of United Kingdom Inflation”, Econometrica, 96 (5): 893-920.

European Mortgage Federation (2011), Representative Interest Rates on New Mortgage Loans, Brussels: Hypostat 2010.

Fair, R.C. (1972), "Disequilibrium in Housing Models", The Journal of Finance, 27 (2): 207-221.

Feroli, M.E., Harris, E.S., Sufi, A. and West, K.D. (2012), "Housing, Monetary Policy, and the Recovery", Chicago Booth Paper no. 12-16, Chicago: University of Chicago. 
Godfrey, L.G. (1978), “Testing Against General Autoregressive and Moving Average Error Models when the Regressors Include Lagged Dependent Variables", Econometrica, 46 (6): 1293-1302.

Gounopoulus, D., Merikas, A.G., Merika, A.A. and Triantafyllou, (2012), "Explaining House Price Changes in Greece", Applied Financial Economics, 22 (7): 549-561.

Gujarati, D. (1997), Econometría Básica, Bogotá: McGraw-Hill Interamericana.

Hendry, D. and Richard, J. (1983), "The Econometric Analysis of Economic Time Series”, International Statistics Review, 51 (2), 3-33.

Hendry, D. and Nielsen, B. (2007), Econometric Modeling, Princenton: Princenton University Press.

Hilbers, P., Hoffmaister, A.W., Banerji, A. and Shi, H. (2008), "House Prices Developments in Europe: A Comparison", IMF Working Paper no. 211, Washington, D.C.: International Monetary Fund.

Hirata, H., Kose, M.A., Otrok, C. and Terrones, M.E. (2012), "Global House Prices Fluctuations: Synchronization and Determinants", NBER Working Paper no. 18362, Cambridge MA: National Bureau of Economic Research.

Jarque, C.M. and Bera, A.K. (1980), "Efficient Tests for Normality, Homoscedasticity and Serial Independence of Regression Residuals", Economics Letters, 6 (3): 255259.

Jarque, C.M. and Bera, A.K. (1981), "Efficient Tests for Normality, Homoscedasticity and Serial Independence of Regression Residuals: Monte Carlo Evidence", Economics Letters, 7 (4): 313-318.

Ketchum, M.D. (1954), "Forecasting Capital Formation in Residential Housing", The Journal of Business, 27 (1): 32-40.

Kwiatkowski, D., Phillips, P.C.B., Schmidt, P. and Shin, Y. (1992), "Testing the Null Hypothesis of Stationarity against the Alternative of a Unit Root: How Sure Are We that Economic Time Series Have a Unit Root?", Journal of Econometrics, 54 (1-3): 159-178.

Leamer, E.E. (2007), "Housing is the Business Cycle", NBER Working Paper no. 13428, Cambridge MA: National Bureau of Economic Research.

Maisel, S.J. (1967), "The Effects of Monetary Policy on Expenditures in Specific Sectors of the Economy", Journal of Political Economy, 76 (4): 796-814.

Merton, R.K. (1968), Social Theory and Social Structure, New York: Free Press.

Milanovic, B. (2011), "More or Less", Finance and Development, International Monetary Fund, 48 (3): 6-11.

Nelson, C.R. and Plosser, C. (1982), "Trends and Random Walks in Macroeconmic Time Series: Some Evidence and Implications", Journal of Monetary Economics, 10 (2): 139-162. 
Peek, J. and Wilcox, J.A. (2006), "Housing, Credit Constraints, and Macro Stability: The Secondary Mortgage Market and Reduced Cyclicality of Residential Investment", The American Economic Review, 96 (2): 135-140.

Perloff, J.M. (2009), Microeconomics (5th ed.). New York: Pearson Education Inc. New York: Pearson.

Phillips, P.C.B. and Perron, P. (1988), "Testing for a Unit Root in Time Series Regression”, Biometrika, 75 (2): 335-346.

Poterba, J.M. (1984), "Tax Subsidies to Owner-Occupied Housing: An Asset-Market Approach", The Quarterly Journal of Economics, 99 (4): 729-752.

Rodríguez, C. and Bustillo, R. (2010), "Modelling Foreing Real Estate Investment: The Spanish Case", The Journal of Real Estate Finance and Economics, 41 (3): 354367.

Shiller, R.J. (2007), "Understanding Recent Trends in House Prices and Home Ownership", NBER Working Paper no. 13553, Cambridge MA: National Bureau of Economic Research.

Stein, G.M. (2012), "Is China's Housing Market Heading Toward a US-Style Crash?", Arizona Journal of International and Comparative Law, 29 (1): 1-42.

The Economist (2012a), Global House Prices. Downdraft, 31 March.

The Economist (2012b), The Housing Market Pulling its Weight at Last, 4 August.

White, H. (1980), “A Heteroskedasticity-Consistent Covariance Matrix Estimator and a Direct Test for Heteroskedasticity", Econometrica, 48 (4): 817-838. 